\title{
An Evalution of Earthquake Hazards of the Grand Teton National Park Emphasizing the Teton Fault
}

\section{Authors}

Robert B. Smith, John O. D. Byrd, Ronald L. Bruhn, David D. Susong, Arthur G. Sylvester, and John W. Geissman 


\title{
An Evaluation of Earthquake Hazards of the Grand Teton National Park Emphasizing THE Teton FaulT
}

\author{
ROBERT B. SMITH $\downarrow$ John O. D. BYRD $\downarrow$ Ronald L. BruHN \\ DEPARTMENT OF GEOLOGY AND GEOPHYSICS \ UNIVERSITY OF UTAH \\ Salt LaKe City
}

\author{
DAVID D. SUSONG \\ U.S. GEOLOGICAL SuRVEY
}

ChEYENNE

\author{
ARTHUR G. Sylvester \\ UNIVERSITY OF CALIFORNIA \\ SANTA BARBARA
}

\author{
John W. Geissman \\ UNIVERSITY OF NEW MEXICO \\ AlbuQuerQue
}

The Teton fault is a major, range-front normal fault that bounds the east side of the $\sim 70 \mathrm{~km}$-long Teton Range, located in northwestern Wyoming. It is an integral component of the $1,300 \mathrm{~km}$-long Intermountain Seismic Belt, an active zone of intraplate seismicity that extends from southern Utah, northward through western Wyoming, eastern Idaho and western Montana. Geologically the Teton fault has evolved in the last 7 to 9 million years accumulating 6 to $9 \mathrm{~km}$ of displacement, concomitant with the development of the Basin-Range extensional tectonics in western Wyoming. In the past 5 to 8 million years, the nearby Yellowstone hotspot has likely influenced the activity of the fault including the timing and amount of slip on the fault. Quaternary scarps of the Teton fault extend for $\sim 55 \mathrm{~km}$, north-south along the east side of the Teton Range and provide excellent exposures of the Teton fault. The Teton fault is the primary structure responsible for producing more than $2,100 \mathrm{~m}(7,000 \mathrm{ft})$ of vertical topographic relief of the range front and is the single most important factor contribution to the spectacular topography and scenery of the Teton Range - hence to the essence of the Grand Teton National Park.

Attesting to the size and youthfulness of the Teton fault is the realization that this major structure is also fully capable of producing major, scarp-forming and damaging earthquakes of magnitudes as large as $M_{s}$ $7.2 \pm 0.3$ and thus represents an important long-term, natural hazard of this region. To evaluate earthquake potential and related earthquake hazards in Grand Teton National Park and the surrounding region, scientists and students of the University of Utah have conducted three years of research (spring 1987 to spring 1990) funded by the University of Wyoming-National Park Service Research Center with supplemental support from the U.S. Geological Survey. This study focussed on an evaluation of the earthquake capability of the Teton fault through the integration of geophysical, geologic, and geodetic data. We targeted such topics as timing, magnitude and long-term deformation rates, and will suggest scenarios of possible ground deformation associated with future earthquakes in a later report. 


\section{Quaternary Faulting OF THE TETON FAULT}

The Quaternary (approximately last 2 million years) expression of the Teton fault consists of two to three independent fault segments, 13 to $42 \mathrm{~km}$ long, that are marked by Holocene (post-glacial and less then 14,000 to 30,000 year old) fault scarps. On the basis of 25 precisely surveyed topographic profiles of scarps of the Teton fault, post-glacial surface offsets have been determined to range from 3 to $35 \mathrm{~m}$, averaging $13 \mathrm{~m}$ in height in the southern segment, and $15 \mathrm{~m}$ in the middle segment. Scarp heights on the other hand, are rather large and exceed $50 \mathrm{~m}$ in the middle segment. In addition, there is some evidence of a 50\% component of left-lateral strike-slip displacement in the central part of the fault zone which suggests that the post-glacial slip on the fault may actually exceed that indicated by the surface offsets.

Extrapolation of the maximum segment lengths of normal faults to the magnitudes of modern earthquakes suggests that the individual segments of the Teton fault may have generated $M_{s}=6.8 \pm 0.3$ earthquakes in the past. However, if a single event involved the entire 55 $\mathrm{km}$ long Teton fault, it would have produced by an $\mathrm{M}_{\mathrm{s}}$ $=7.2 \pm 0.3$ earthquake.

\section{SeISMIC GaP}

Despite the evidence for contemporary earthquake activity in the surrounding region, the Teton fault occupies a prominent gap in the historic seismicity of the Intermountain Seismic Belt. On the basis of the Holocene history of faulting and the long-term geologic record, however, we do not believe that the Teton fault is inactive. The Teton fault may thus be storing stress and could be expected to "fill in" with a moderate to large earthquake in the future.

Alternately, it may reflect seismic quiescence due to strain redistribution on other structures such as reflected in the modern seismicity of the Gros Ventre Range, or it may not be accumulating stress at this time for an unknown reason. We do not have adequate information at this time to determine the state of stress on the Teton fault.

\section{TIMING OF FAULTING}

To determine the age and amount of slip associated with the most recent ground-breaking, pre-historic earthquakes of the Tetonfault, a $3.6 \mathrm{~m}$ fault scarp at the mouth of Granite Canyon was excavated by trenching in 1989 . This trench exposed $4.1 \mathrm{~m}$ of fault displacement related to one, and possibly two, scarp-forming prehistoric earthquakes. The oldest, and most well constrained event occurred $7980 \pm 210$ years before present ( $7175 \pm 100$ radiocarbon years). Dating of charcoal samples (in progress) will help us determine if the $4.1 \mathrm{~m}$ displacement is solely the product of a single 7980 year old event, or if a younger ground rupturing earthquake has contributed to the total displacement. If the $4.1 \mathrm{~m}$ event represents a single displacement event it would have been associated with an estimated magnitude of $\mathrm{M}_{\mathrm{s}} 7.2 \pm 0.3$ earthquake that would likely have ruptured the entire length of the Teton fault.

Combining the ages of faulting determined from the trench at Granite Canyon with the determinations of surface offsets from the Quaternary scarp profiles provides estimates of fault slip rates due to multiple, prehistoric earthquakes on the Teton fault. These data yield recurrence intervals for large, ground breaking earthquakes of M 7+ of 1650 to 6060 years.

Corresponding slip rates on the fault range from 0.45 $\mathrm{mm} / \mathrm{yr}$ slip rate, assuming a 30,000 year age of glacial cessation, from the 7,175 years b.p. displacement event and tied to the age of most recent faulting determined at Granite Canyon to the present, suggests that the southern segment of the Teton fault may be storing stress at a normal rate. On a more problematical basis, extrapolating the $1.6 \mathrm{~mm} / \mathrm{yr}$ slip rate, assuming a 14,000 year glacial cessation date, forward in time from the 7,175 year old event, suggests that the southern segment and may have already stored sufficient stress to generate a M 7+ earthquake that would effectively fill in the seismic gap. However, because we do not know the actual state of stress on the fault, we can not confidently state the current state of earthquake potential without more information.

\section{EARTHQUAKE INDUCED GROUND DEFORMATION}

Ground deformation, in particular the extent and magnitude of subsidence of the hanging-wall block, associated with three large historic normal faulting earthquakes in the western U.S. has been well documented. These earthquakes are:

1. the $M_{s} 7.3,1983$, Borah Peak, Idaho,

2. the $M_{s} 7.5,1959$, Hebgen Lake, Montana, and

3. the $M_{s} 6.8,1954$, Dixie Valley, Nevada, earthquakes. 
We have used a hypothetical working model determined from observations of these large earthquakes to tentatively identify a north-south trending area of topographic subsidence up to $\sim 29 \mathrm{~m}$ deep and approximately $8 \mathrm{~km}$ long (north-south) and 2 $\mathrm{km}$ (east-west), adjacent to and east of the middle section of the Teton Range. This unusual depression may reflect, in part, tectonic surface deformation (hanging wall subsidence) associated with fault displacements from large pre-historic scarp forming earthquakes, exceeding $M_{s} 6.3$, on the Teton fault. This subsidence feature appears to have contributed to the range-front capture of streams flowing eastward from the central Teton range and produces an anomalous southward drainage pattern rather than eastward drainageinto the Snake River. However, the subsidence area is also likely influenced by a combination of tectonic activity, stream channeling, and aggradation from ancient flow channels emanating from the ancient Jackson Lake and we have not yet determined the relative amount of tectonic versus depositional deformation in this area.

Preliminary modeling of detailed topographic profiles across the depression, assuming an seismotectonic origin, suggests that the subsidence could have been produced by as many as 5 to 10 large ground breaking $\mathrm{M} 7+$ earthquakes on the Teton fault in the past 14,000 years with an average recurrence interval of 1,500 to 6,000 years. These results are considered preliminary since the ages of the tilted surfaces on the valley floor are poorly known, and no attempts have been made yet to remove pre-existing depositional slope, or the effects of aggradation of fluvial sediments.

\section{Teton Fault Level Line}

Contemporary deformation associated with active faults is considered a key element of an earthquake hazard assessment. In a cooperative project between the University of Utah and the University of California at Santa Barbara, we have conducted two precise elevation surveys of an east-west leveling profile across the middle segment of the Teton fault. The 22 $\mathrm{km}$ long level line extends from the head of Cascade Canyon eastward across the fault at Jenny Lake to Deadmans Bar on the Snake River and was established in 1988 to $1^{\text {st }}$ order surveying standards. The results of the initial 1989 re-observation of this $1^{\text {st }}$ order level line indicates that the footwall block, the Teton Range, subsided up to $7.8 \mathrm{~mm} \pm 0.7 \mathrm{~mm}$ relative to valley floor, in the one year period. Geologically we expected the mountain block to rise rather than subside, thus this observation of mountain block subsidence is considered very unusual and may reflect unknown processes related to the seismic quiescence of the Teton fault.

There are several explanations for this unusual aseismic behavior, such as interseismic energy accumulation, seismic energy release in the Gros Ventre block to the east that is locking the Teton fault, or possible relative footwall subsidence that may be due to lateral compression (deviatoric compression) on a uniform upper-crustal block, including the fault. Nonetheless, the measured deformation occurred as aseismic creep, i.e., without accompanying earthquakes. These observations notably represent the first documented occurrence of aseismic creep across a major normal fault, as well as the first case of vertical creep reported anywhere in the world, aside from afterslip or subsidence of blocks in mid-ocean rift zones.

\section{Paleomagnetic Measurements of FaUlt Deformation}

In a cooperative project with John Geissman of the University of New Mexico, analyses of paleomagnetic samples collected at 67 sites in the Huckleberry Ridge tuff, a 2.0 million year old volcanic unitassociated with the Yellowstone caldera and deposited across the Teton range, allows the determination of the post 2 million year deformation of the Teton Range and the adjacent valley associated with the long term activity of the Teton fault. These analyses suggest that the westward back-tilting of the Huckleberry Ridge tuff in the Teton Range (footwall) and Jackson Hole (hangingwall) may be entirely due to movement on the Teton fault, with as much as 2,800 meters of vertical displacement. This observation establishes a displacement rate of $1.4 \mathrm{~mm} / \mathrm{yr}$ for the Teton fault for the last $2 \mathrm{~m} . y$. that is consistent with the post-glacial displacement rates, and is significantly higher than those determined for other normal faults in the region.

\section{$\downarrow$ Overview}

Tectonic modeling of topographic profiles, along with determination of slip rates from the trenching and paleomagnetic analyses suggest that the long-term Quaternary displacement rates of the Teton fault range from 0.45 to $1.6 \mathrm{~mm} / \mathrm{yr}$. These long-term average 
rates are notably larger than Quaternary deformation rates measured on other large and active normal fault zones of the western U.S. These observations suggest a rather uniform long-term average displacement rate on the Teton fault for the last two million years. There is no definitive evidence that the displacement rates on the Teton fault have changed in historic time, hence there is no reason to suggest that the earthquake activity has changed from that deduced from the Quaternary record.

The significance of these findings on the earthquake potential of the Teton region is important when one considers the similarities of the Teton fault with the seismotectonics of the three well- studied, large normal faulting earthquakes in the Basin-Range in historical time (described above). Analyses of these earthquakes suggest that they occurred at or near the lateral boundaries of fault segments on $40^{\circ}$ to $60^{\circ}$ dipping planar faults, nucleating at mid-crustal depths of 12 to $16 \mathrm{~km}$. Unilateral rupture from near the ends of fault segments was noted for the Borah Peak earthquake and suggested for the Hebgen Lake earthquake. We suggest that these faulting characteristics provide a hypothetical working model for a ground breaking, $6.3 \leq \mathrm{M}_{\mathrm{s}}<7.5$, normal faulting earthquakes that can be applied to the Teton and other large normal faults of the Intermountain region.

On the basis of the long-term record of earthquakes in the region, future earthquakes of magnitude $6.3 \leq M_{s}<7.5$ are expected to continue in the Hebgen Lake-Yellowstone-Teton region with expected recurrence intervals on the order of 1,000 's of years. While the repeat times are large compared to expected lifetimes of man-made structures and of man himself, the occurrence of such large earthquakes can have a significant impact on the surrounding areas. Such factors as disruption of lifelines (roads, power lines, water lines, etc.), damage to man-made and natural structures, and loss of life may result from ground deformation and strong ground shaking that could accompany such events (depending on the locationof the epicenter with respect to the structure). Secondary effects of these large earthquakes could also include landslides, avalanches, and flooding.

Increased knowledge and recognition of earthquake processes and the earthquake potential of the region by local, state and federal officials and the general public can significantly mitigate the effects of a major earthquake. Furthermore, an understanding of active geologic processes in the Teton region can lead to informed emergency and land management decisions and policies by public officials that lead to an increased awareness of the seismic hazard and recognition of safety precautions that can be taken by the general public.

The results of our research to date provide the first direct information for estimating the maximum magnitude of earthquakes, and their effects, that could occur on the Teton fault. The results, together with estimates of long-term slip rates, also provide a measure of the time history of the fault that is useful for long-term assessments of the earthquake hazards of Grand Teton National Park and surrounding region. 